\title{
EFFICACY OF AVENA SATIVA L. AND TRIFOLIUM ALEXANDRINUM L. TEST SYSTEM FOR DETECTING THE GENOTOXIC AND PHYTOTOXIC POTENTIAL OF WATER POLLUTION
}

\author{
KHELIF, L. ${ }^{1}-$ BELLOUT, Y. $^{2}-$ DJEBBAR, R. ${ }^{1}-$ ABROUS-BELBACHIR, O. ${ }^{1 *}$ \\ ${ }^{1}$ Laboratory of biology and Physiology of organisms, Faculty of Sciences, University of \\ Sciences and Technology Houari Boumediene- BP 32 El Alia-16111-Algeria \\ ${ }^{2}$ Department of Biology, Faculty of Sciences, University Mhamad Bougara Boumerdes- Algeria \\ *Corresponding author \\ e-mail: oabrous@yahoo.fr \\ phone: +213-21-24-72-17; fax: +213-21-24-79-50 \\ (Received $17^{\text {th }}$ Jun 2016; accepted $8^{\text {th }}$ Aug 2016)
}

\begin{abstract}
The Reghaïa Lake (Algiers, Algeria) is contaminated by the untreated industrial effluents discharge of Reghaïa-Rouiba industrial park, via El Biar River. The present report is the first study which addresses the effects of industrial wastewaters rejected into the lake in light of genotoxic and phytotoxic effects, using Avena sativa $\mathrm{L}$. and Trifolium alexandrinum $\mathrm{L}$. test system. The wastewaters were collected seasonally at the mouth of El Biar River and analyzed using chemical analysis and biological assays, including the germination and root elongation inhibition test, mitotic index and micronucleus test. Results showed that samples collected during the summer season (SM) were high contaminated by heavy metals than that of the winter season (WN). Furthermore, the WN samples have relatively low phytotoxicity on A. sativa seed germination and T. alexandrinum root elongation (no EC50 was determined). Genotoxicity of the SM samples is evident in A. sativa by a significant depression of mitotic activity, induction of several chromosomal aberrations and occurrence of micronuclei in T. alexandrinum. All the results indicated that the samples from the El Biar discharging river in Reghaïa Lake exhibited genotoxicity and argue for the possible use of A. sativa and $T$. alexandrinum plant system for genotoxicity assays.
\end{abstract}

Keywords: industrial effluents, heavy metals, Reghaïa Lake, plant biotests, genotoxicity

\section{Introduction}

In Algiers, capital of Algeria, industrial effluents discharge into rivers, are the major sources of aquatic pollution. Reghaïa Lake in northeast of Algiers has a total surface area about 75 ha of freshwater. It was promoted in 1993 as a Ramsar lake site and represents the only remnant of the Mitidja old swamp. The lake is affected by industrial effluents from Reghaïa-Rouiba industrial areas (tanneries, chemical and allied products, leather, pulp and paper, and miscellaneous industrial activities). Monitoring of the Reghaïa Lake, based on physical and chemical analyses of surface-water quality (Algerian legislation does not include toxicity evaluation), indicates that many toxic chemicals are found in water. The common components which are heavy metals $(\mathrm{Cd}$, $\mathrm{Cr}, \mathrm{Fe}, \mathrm{Ni}, \mathrm{Pb}$ and $\mathrm{Hg}$ ), transported largely by El Biar River (Thibault et al., 2006; Taleb et al., 2008). Water pumped from the lake is crucial for agricultural use in the southern Reghaïa region. The application of wastewater on agricultural land may cause accumulation of metals and persistent organic chemicals in soils and agricultural products, which can potentially harm human and animal health (Garg and Kaushik, 2007; Liu et al., 2015). 
Since chemical analysis is cumbersome and does not warrant exhaustive coverage of all potential toxic substances, biotests have been developed to define the toxic effects of industrial wastewaters at different concentrations and exposure periods (Reifferscheid et al., 2008; Llorente et al., 2012). Metals when in excess into the exposure pathways, cause lethal effects, genotoxicity, mutagenicity, and carcinogenicity to microorganisms, aquatic organisms, plants, animals, and human beings (Singh et al., 2014). Therefore, the use of plant bioassays for the genotoxicity evaluation is pivotal since plants are the primary target of noxious substances and these tests are relatively simple to perform, economic, biologically sensitive, and rapid (Fatima and Ahmad, 2006; Mielli et al., 2009). Moreover, inhibition of seed germination and the growth of root and shoot represent excellent biological tests easy to perform, and reliable if compared to other biological test-systems (Siddiqui et al., 2011).

Screening of genotoxic effects of various chemicals has been reported using different plant systems. Among higher plants, Allium cepa has been considered an efficient test organism (Firbas and Amon, 2014; Pathiratne et al., 2015). On the other hand, a number of studies show that Vicia faba is appropriate for pursuing the genotoxicity evaluation and it has more advantages than the other plants (e.g., Tradescantia paludosa and Allium cepa) (Cotelle et al., 1999). Moreover, Arabidopsis thaliana (Filkowski et al., 2003; Li et al., 2010), Hordeum vulgare (Grant, 1978; Kamal et al., 1992; Sang et al., 2006; Srivastava et al., 2014), Triticum aestivum (Kumar, 2010) and Trifolium repens, (Manier et al., 2009) have been also used and considered as an excellent indicators of genetic damage. The micronuclei formation test, introduced by Levan (1938), is the most frequently used, effective and the simplest indicator of DNA damage (Pathiratne et al., 2015).

There are only a few reports published till date which describe the heavy metal contamination of the surface water (Taleb et al., 2008) and sediments (Alomary and Belhadj, 2007) of the Reghaïa Lake, however no study has focused on the genotoxicity of industrial wastewaters rejected into this lake. Nevertheless, adequate attention has not yet been given in Algeria to test the toxicity/genotoxicity of the complex industrial effluents. Concerning the genotoxicity of different types of industrial wastewater, many studies have focused on this thematic. Only a few published works concerning the genotoxic effects of irrigative industrial wastewater are available. In addition, all the developed models are cultivated vegetable plants, such as Vicia faba and Allium cepa and scarce works presented results on other plant systems. In this work, we have chosen to screen the genotoxic response using $A$. sativa and $T$. alexandrinum plant system, which are not a model system for genotoxicity test and have never been used in this domain, but represents the best example of rapid cycle plant system recommended by the OECD for ecotoxicological testing and widely cultivated around the Reghaïa Lake as fodder plant. These two plant species represent grasses and legumes and are commonly used also in revegetation practices. The present report is the first study which addresses the effects of industrial wastewater rejected into Reghaïa Lake in light of genotoxic and phytotoxic effects.

The aims of the present researches are to investigate the quality/toxicity of the industrial wastewaters rejected from Reghaïa-Rouiba industrial area into Reghaïa Lake (located in the northeast of Algeria) using plant bioassays with Avena sativa L. and Trifolium alexandrinum L. test system. Inhibition of germination and root elongation was carried out to determine the phytotoxicity of contaminated water. In addition, the 
Mitotic index (MI), micronucleus (MN) test and pollution index (PI) were performed to detect the potential genotoxicity and cytotoxicity of industrial wastewater.

\section{Materials and methods}

\section{Site description}

The Reghaïa Lake has a total surface area of 75 ha of freshwater. It opens to the Mediterranean Sea from its northern edge. The lake is situated about $35 \mathrm{~km}$ northeast Algiers $\left(3^{\circ} 19^{\prime}-3^{\circ} 21^{\prime} \mathrm{E}, 36^{\circ} 45^{\prime}-36^{\circ} 48^{\prime} \mathrm{N}\right)$ (Fig. 1) and located in the downstream of Reghaïa-Rouiba industrial park, which constitute the major sources of water contamination by metal trace elements. Creates in 1960, the industrial park extends on a surface of 1000 ha and contains more than 300 industrial plants (tanneries, chemical and allied products, leather, pulp and paper, and miscellaneous industrial activities). Most effluents are not treated before to be released in the river. The wastewater volume rejected by the whole industrial zone is estimated at more than $20000 \mathrm{~m}^{3} /$ day. These effluents have high heavy metals $(\mathrm{Cd}, \mathrm{Cr}, \mathrm{Cu}, \mathrm{Fe}, \mathrm{Ni}, \mathrm{Pb}$ and $\mathrm{Zn}$ ) and suspended solid (SS) concentrations, and are characterized by excessive mineralization (Thibault et al., 2006; Taleb et al., 2008).

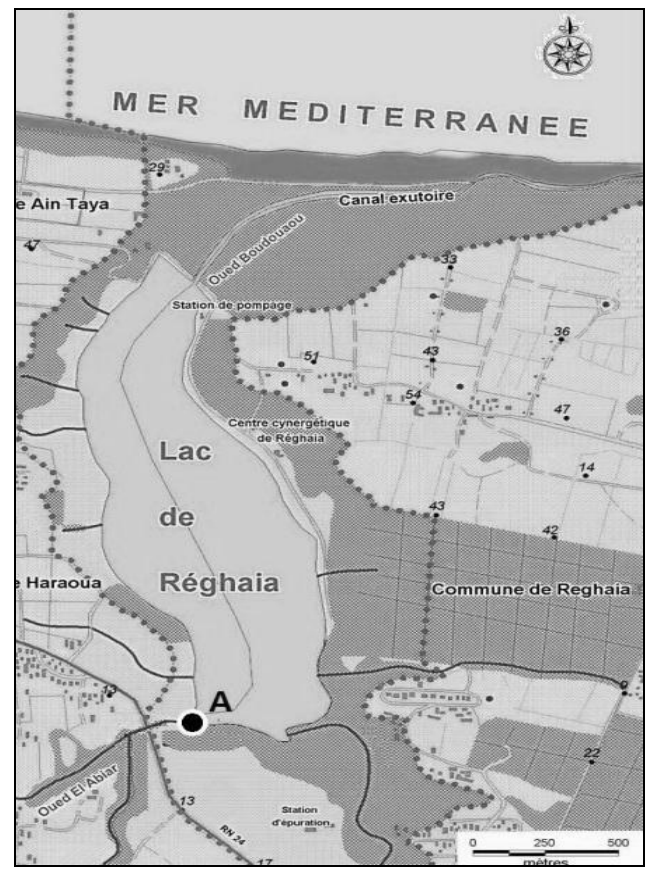

Figure 1. Geographic situation of the Reghaïa Lake. A: sampling station, at the mouth of El Biar River

\section{Effluents}

Water samples were collected at the mouth of El Biar River discharging into the Reghaïa Lake (A: $3^{\circ} 19^{\prime} 58^{\prime \prime}$ E - 36 $6^{\circ} 45^{\prime} 44^{\prime \prime} \mathrm{N}$ ). These samples represent the sum of whole industrial effluents released by factories in El Biar River, entering the lake. Surface water was collected in polyethylene containers of 5-litre capacity at two different periods, series 1: January- February (winter) and series 2: July-August (summer) 2015. 
For each series three samples were performed. The collected samples were transported to the laboratory and immediately stored in cold room at $4{ }^{\circ} \mathrm{C}$. The physicochemical parameters of samples ( $\mathrm{pH}$, temperature (T), dissolved oxygen (DO) content, biochemical oxygen demand $\left(\mathrm{BOD}_{5}\right)$, chemical oxygen demand $(\mathrm{COD})$, total suspended solid (TSS), total phosphate (TP), total organic carbon (TOC), nitrates $\left(\mathrm{NO}_{3}{ }^{-}\right.$), ammonium $\left(\mathrm{NH}_{4}^{+}\right)$, nitrites $\left(\mathrm{NO}_{2}^{-}\right)$, total hydrocarbons (THC), sodium (Na), potassium $(\mathrm{K})$, magnesium $(\mathrm{Mg})$ and calcium $(\mathrm{Ca})$ ) were measured. In addition, metal contents $\left(\mathrm{Hg}, \mathrm{Fe}^{2+}, \mathrm{Cd}\right.$, Total $\mathrm{Cr}, \mathrm{Cu}, \mathrm{Ni}, \mathrm{Pb}$ and $\left.\mathrm{Zn}\right)$ were measured using Inductively Coupled Plasma-optical emission spectrometry (ICP-OES) according to the ISO 11885 protocol (ISO, 2007). To evaluate ecotoxicological effects of water samples on A. sativa and $T$. alexandrinum, undiluted (100\%) and diluted water at 25, 50 and $75 \%$ of each sample were tested. The dilutions were prepared with distilled water.

\section{Germination test}

Germination test with one monocotyledonous plant, Avena sativa L., and one dicotyledonous plant, Trifolium alexandrinum L. was performed on wastewater samples. Both plant species are used as fodder plant and recommended by the OECD for ecotoxicological testing. Seeds were obtained commercially and sorted based on size and appearance. The test was made in accordance with the OECD Guideline 208 A (OCED, 1984). Seeds were surface sterilized with $0.1 \%$ sodium hypochlorite $(\mathrm{NaClO})$ for $10 \mathrm{~min}$, rinsed three times and soaked in distilled water at room temperature for 12 h. 10 seeds of $A$. sativa or 20 seeds of T. alexandrinum were subjected to germination in plastic Petri dishes lined with an absorbent paper, moistened with $5 \mathrm{ml}$ of distilled water (control), 25, 50, 75, or $100 \%$ of wastewater samples collected during the winter (WN) season or summer $(\mathrm{SM})$. In order to test 100 seeds of each species, ten replicates $(10 \times 10$ seeds) for $A$. sativa and five $(5 \times 20$ seeds $)$ for $T$. alexandrinum were maintained for each treatment at $25^{\circ} \mathrm{C}$. After seven days, the number of germinated seeds was counted, and expressed as germination rate. The EC50 (concentrations with 50\% maximum possible effect) values of germination inhibition were calculated for each sample (WN and SM).

\section{Root elongation test}

The root elongation (RE) toxicity test was performed in accordance with the OECD for plant acute toxicity tests (OECD, 1984). All bioassays had five replicates per treatments and control. Each replicate is a culture dish (diameter: $20 \mathrm{~cm}$ ) with $100 \mathrm{~g}$ of artificial soil ( $70 \%$ sand, $20 \%$ clay and $10 \%$ peat, by dry weight). The soil was watered with pure water for the controls, with $25,50,75$, or $100 \%$ of each sample according to usable water to field capacity calculated in gram of water per gram of artificial soil and after wards, every other day till the end of the experiment. For each dish, either 20 pregerminated seeds of $A$. sativa or $T$. alexandrinum were placed in soil. The seedlings were then grown in a growth chamber with $16 \mathrm{~h}$ light and $8 \mathrm{~h}$ dark cycle at a constant temperature of $25^{\circ} \mathrm{C}$ and relative air humidity of $60 \%$. After 5 days, the root elongation was measured in all treatments. The inhibitory rate (IR) of the two plants was calculated as followed:

$$
\mathrm{IR}=\frac{\text { the root elongation in control treatment }}{\text { the root elongation in sample treatment }}
$$




\section{Plant genotoxicity tests}

Root tip genotoxicity test was carried out on two different plant species A. sativa L. (number of chromosomes: $2 \mathrm{n}=42)$, and T. alexandrinum L. $(2 \mathrm{n}=16)$. As described previously, seeds of both species were allowed to germinate for 3 days in the same conditions of the germination tests. When the primary root reached $1-2 \mathrm{~cm}$ in length, the root tip was cut off $(2-3 \mathrm{~mm})$ to stimulate the development of secondary roots. Then, the roots were exposed to fresh Hoagland's solution (negative control) or to wastewater samples collected during the winter season (WN) or summer (SM) at concentrations of $25 \%, 50 \%, 75 \%$ and $100 \%$. As a positive control, methyl methane sulphonate (MMS at $10 \mathrm{mg} / \mathrm{L})$ was used.

After 4 days, root tips $(20 \mathrm{~mm})$ of $A$. sativa $\mathrm{L}$. and $T$. alexandrinum $\mathrm{L}$. were excised and fixed overnight in Carnoy's solution (1:3 glacial acetic acid and ethanol) and then transferred to $70 \%$ ethanol for storage (Monarca et al., 2005). Before the microscopic observation, roots were hydrolyzed in $1 \mathrm{~N} \mathrm{HCl}$ at $60^{\circ} \mathrm{C}$ for 6 to $7 \mathrm{~min}$, five root tips per experimental group were used for preparing slides. After staining the root tips with $1 \%$ aceto-orcein, the slides were viewed under the light microscope using the $100 \times$ objective lens with oil immersion.

The genotoxicity potencies of individual samples based on the MN frequencies (a number of cells with micronuclei per 1,000 cells scored) and the pollution index (PI) value were determined. The identification of PI has been used for the classification of the polluted water. The mitotic index (MI) was expressed as the number of dividing cells per 100 scored cells. The MI was also recorded as an indicator of the cytotoxicity.

$$
\mathrm{MN} \%_{0}=\frac{\text { Number of cells containing micronucleus }}{\text { Total number of cells counted }}
$$

$$
\mathrm{PI}=\frac{\text { MN of the sample }}{\mathrm{MN} \text { of the negative control }}
$$

\section{Statistical analysis}

ANOVA analysis was used to determine the overall significance of the doseresponse relationship (sample-genotoxicity) and followed by post-hoc Tukey tests to determine which dose levels were different from the negative control at 5\%,1\% and $0.1 \%$ significance level. The EC50 values (concentrations with 50\% maximum possible effect) of germination and root elongation inhibition test were calculated using a ProbitAnalysis. All tests were performed using the statistical software package Statistica 10 (StatSoft, 2011).

\section{Results and discussion}

\section{Physicochemical analyses}

Mean values of water chemical parameters for samples collected during the winter season (WN) and summer (SM) 2015 are presented in Table 1. Analysis of parameters 
$\mathrm{COD}, \mathrm{TOC}, \mathrm{BOD}_{5}$ indicated that organic contents of $\mathrm{WN}$ and $\mathrm{SM}$ samples were higher than regulatory limits set by the National Agency for water resources (Table 1.). Despite that, their biodegradability, expressed as $\mathrm{BOD}_{5} / \mathrm{COD}$ ratio was on similar level $(0.39$ and 0.46, respectively). In contrast, in the summer season (SM) there was an increase in the rates of total phosphate (TP), total organic carbon (TOC), total suspended solids (TSS) and ammonia in samples. At the same time, there were decreases in $\mathrm{pH}$ and dissolved oxygen (DO) values. The total hydrocarbons (THC) values were on similar level with the regulatory limits. Moreover, the SM samples showed higher contents of metals than those of WN, with total concentrations of metals up to $1637 \mu \mathrm{g} / \mathrm{L}$ and 349 $\mu \mathrm{g} / \mathrm{L}$, respectively. Iron $(\mathrm{Fe})$ is the metal found in the highest concentrations with a maximum concentration of $989 \mu \mathrm{g} / \mathrm{L}$ in SM samples, but significant concentrations of $\mathrm{Cr}(79 \mu \mathrm{g} / \mathrm{L}), \mathrm{Ni}(70.9 \mu \mathrm{g} / \mathrm{L})$, and $\mathrm{Zn}(85 \mu \mathrm{g} / \mathrm{L})$ are also found (Table 1.).

Table 1. Mean values of water chemical parameters measured at the mouth of the El Biar River in the winter (WN) and summer season (SM) 2015

\begin{tabular}{c|c|c|c}
\hline $\begin{array}{c}\text { Analytical } \\
\text { parameter }\end{array}$ & Sample WN & Sample SM & $\begin{array}{c}\text { Limit } \\
\text { value }\end{array}$ \\
\hline $\mathrm{pH}$ & $6.9 \pm 0.9$ & $4.9 \pm 1.5$ & $6.5-8.5$ \\
$\mathrm{~T}\left({ }^{\circ} \mathrm{C}\right)$ & $15.6 \pm 0.8$ & $26.6 \pm 1.1$ & $<25$ \\
$\mathrm{TSS}(\mathrm{mg} / \mathrm{L})$ & $321 \pm 21.6$ & $1088 \pm 42.3$ & $<30$ \\
$\mathrm{DO}(\mathrm{mg} / \mathrm{L})$ & $4.1 \pm 1.0$ & $1.2 \pm 0.2$ & $>7$ \\
$\mathrm{BOD} 5(\mathrm{mg} / \mathrm{L})$ & $334.8 \pm 15.6$ & $876 \pm 56$ & $<5$ \\
$\mathrm{COD}(\mathrm{mg} / \mathrm{L})$ & $849 \pm 98.3$ & $1870 \pm 39.7$ & $<20$ \\
$\mathrm{TOC}(\mathrm{mg} / \mathrm{L})$ & $180 \pm 23.2$ & $320 \pm 46.4$ & 10 \\
$\mathrm{TP}(\mathrm{mg} / \mathrm{L})$ & $0.6 \pm 0.4$ & $20.7 \pm 5.4$ & $<0.2$ \\
$\mathrm{NH}{ }^{+}(\mathrm{mg} / \mathrm{L})$ & $17 \pm 2.4$ & $86 \pm 22.1$ & $<10$ \\
$\mathrm{NO}{ }^{-}(\mathrm{mg} / \mathrm{L})$ & $0.28 \pm 0.1$ & $0.96 \pm 0.4$ & $<5$ \\
$\mathrm{NO}{ }^{-}(\mathrm{mg} / \mathrm{L})$ & $0.06 \pm 0.03$ & $0.32 \pm 0.09$ & 0.01 \\
$\mathrm{THC}(\mathrm{mg} / \mathrm{L})$ & $1.8 \pm 0.09$ & $3.85 \pm 2.15$ & 3.5 \\
$\mathrm{Na}(\mathrm{mg} / \mathrm{L})$ & $176 \pm 23.1$ & $125 \pm 13.3$ & $<100$ \\
$\mathrm{~K}(\mathrm{mg} / \mathrm{L})$ & $27.5 \pm 10.9$ & $14.9 \pm 4.2$ & 10 \\
$\mathrm{Ca}(\mu \mathrm{g} / \mathrm{L})$ & $142.2 \pm 35$ & $205 \pm 68.6$ & $<100$ \\
$\mathrm{Mg}(\mu \mathrm{g} / \mathrm{L})$ & $38.4 \pm 11.7$ & $75.6 \pm 7.8$ & $<30$ \\
$\mathrm{Hg}(\mu \mathrm{g} / \mathrm{L})$ & $2.42 \pm 0.04$ & $23 \pm 1.5$ & 0.0005 \\
$\mathrm{Fe}(\mu \mathrm{g} / \mathrm{L})$ & $136.5 \pm 26.3$ & $989 \pm 96.1$ & 0.1 \\
$\mathrm{Cd}(\mu \mathrm{g} / \mathrm{L})$ & $2.1 \pm 0.1$ & $26 \pm 4.3$ & 0.005 \\
$\mathrm{Cr}(\mu \mathrm{g} / \mathrm{L})$ & $2.5 \pm 1.4$ & $97.2 \pm 34.1$ & 0.01 \\
$\mathrm{Cu}(\mu \mathrm{g} / \mathrm{L})$ & $0.094 \pm 0.0$ & $47 \pm 8.2$ & 0.01 \\
$\mathrm{Ni}(\mu \mathrm{g} / \mathrm{L})$ & $3.86 \pm 1.8$ & $70.9 \pm 3.6$ & 0.01 \\
$\mathrm{~Pb}(\mu \mathrm{g} / \mathrm{L})$ & - & $18.8 \pm 1.1$ & 0.01 \\
$\mathrm{Zn}(\mu \mathrm{g} / \mathrm{L})$ & $21.79 \pm 6.7$ & $85 \pm 15.4$ & 0.3 \\
\hline
\end{tabular}

${ }^{\mathrm{a}}$ : Limit values set by the national agency for water resources (ANRH, 2008), $-<$ Detection under limit of determination.

\section{Germination test}

As shown in Figure 2., there was a significant linear correlation between the germination inhibitory rate of $A$. sativa and the tested concentrations of SM samples ( $P$ $<0.01$ ). According to the corresponding regression equations (listed in Table 2.) based on the inhibition of germination, the EC50 was calculated. It was shown that the EC50 was $59.2 \%$ of SM samples. 


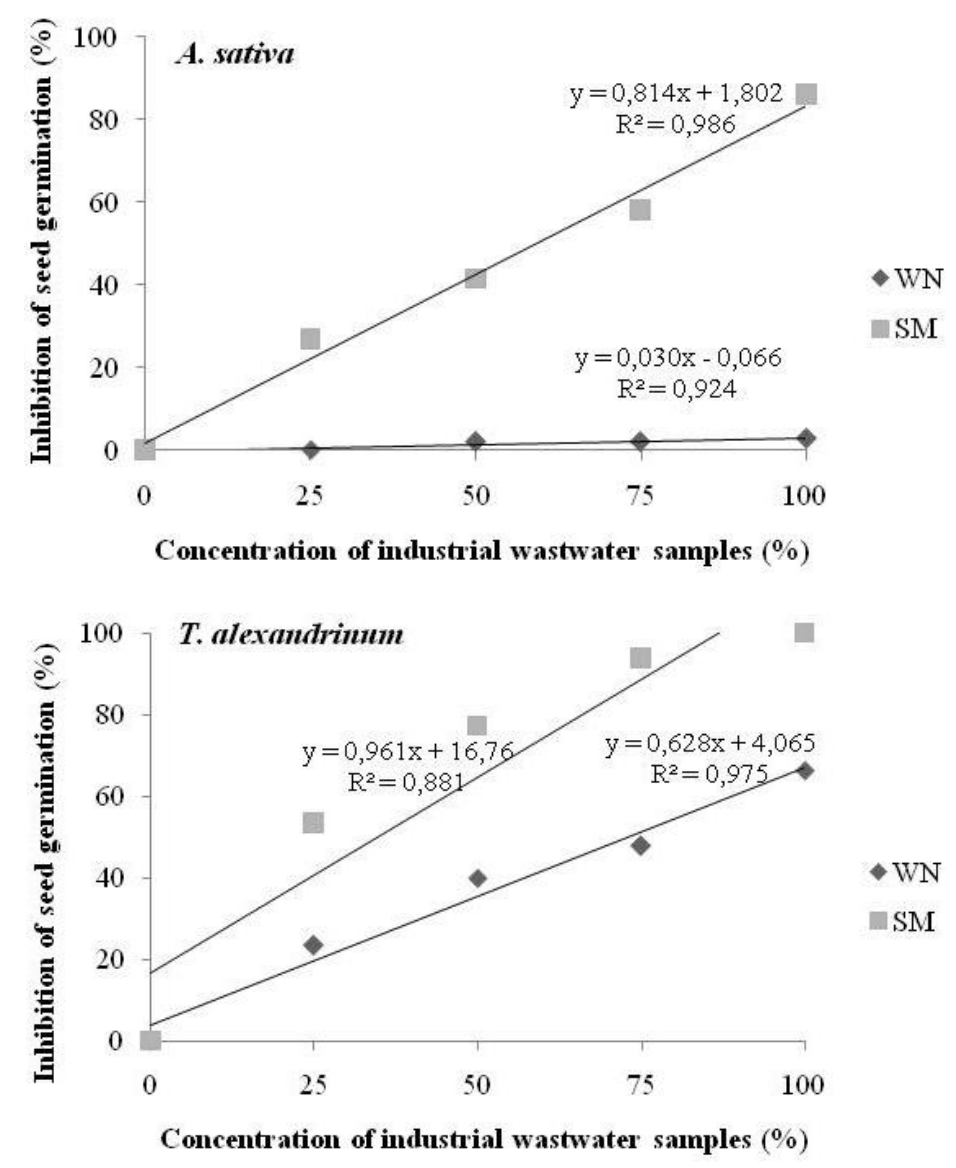

Figure 2. Toxic effects of wastewater samples collected during the winter (WN) and summer season (SM) on the inhibitory rate of seed germination of A. sativa and T. alexandrinum

Table 2. Regression equations, EC50 and EC100 for germination of A. sativa and T. alexandrinum exposed to samples collected during the winter (WN) and summer season (SM)

\begin{tabular}{lccccc}
\hline Plant species & sample & Regression Equation & $\boldsymbol{R}^{2}$ & EC50 (\%) & EC100 (\%) \\
\hline A. sativa & WN & $\mathrm{y}=0.030 \mathrm{x}-0.066$ & $R^{2}=0.924$ & - & - \\
& $\mathrm{SM}$ & $\mathrm{y}=0.814 \mathrm{x}+1.802$ & $R^{2}=0.986$ & 59.2 & - \\
\hline T. alexandrinum & $\mathrm{WN}$ & $\mathrm{y}=0.628 \mathrm{x}+4.065$ & $R^{2}=0.975$ & 73.1 & - \\
& $\mathrm{SM}$ & $\mathrm{y}=0.961 \mathrm{x}+16.76$ & $R^{2}=0.881$ & 34.6 & 87.8 \\
\hline
\end{tabular}

$(-)$ : Not determined

On the contrary, WN samples have relatively low phytotoxicity on A. sativa seed germination. In this case, only the undiluted WN samples reduced significantly $(P<$ $0.01)$ the germination rate. Thus, no EC50 was determined for WN samples, which meant that the toxic effect of SM on A. sativa was stronger than that of WN. 
As shown in Figure 2., there was a clear dose-response between concentration of samples ( $\mathrm{SM}$ and $\mathrm{WN})$ and the germination inhibitory rate of T. alexandrinum.

Table 2. presents the EC50 values obtained after the concentration gradient assay for wastewater samples. The lower EC50 (higher toxicity) was observed with SM samples (34.6\%); while, it was markedly higher with WN samples $(73.1 \%)$, which means that the toxic effect of SM on T. alexandrinum was stronger than that of WN ones. In terms of EC50 of seed germination, the results from the present study indicated that $T$. alexandrinum germination was more sensitive to the toxicity of SM and WN samples than that of A. sativa.

\section{Root elongation test}

To investigate the possible inhibitory effect of the contaminated wastewaters on root elongation, A. sativa and T. alexandrinum seedlings were exposed to both SM and WN samples in laboratory conditions. The dose-response relationships for the root elongation inhibition and the different concentrations of water samples are shown in Figure 3., after 5 day, the root elongation of both plant species decreased significantly at all concentrations of the WN samples but the EC50 was determined only for A. sativa root elongation (72.8\% of WN samples). In terms of EC50 values of the WN samples (Table 3.), on the two plant species, the A. sativa root elongation was more inhibited than that of $T$. alexandrinum.
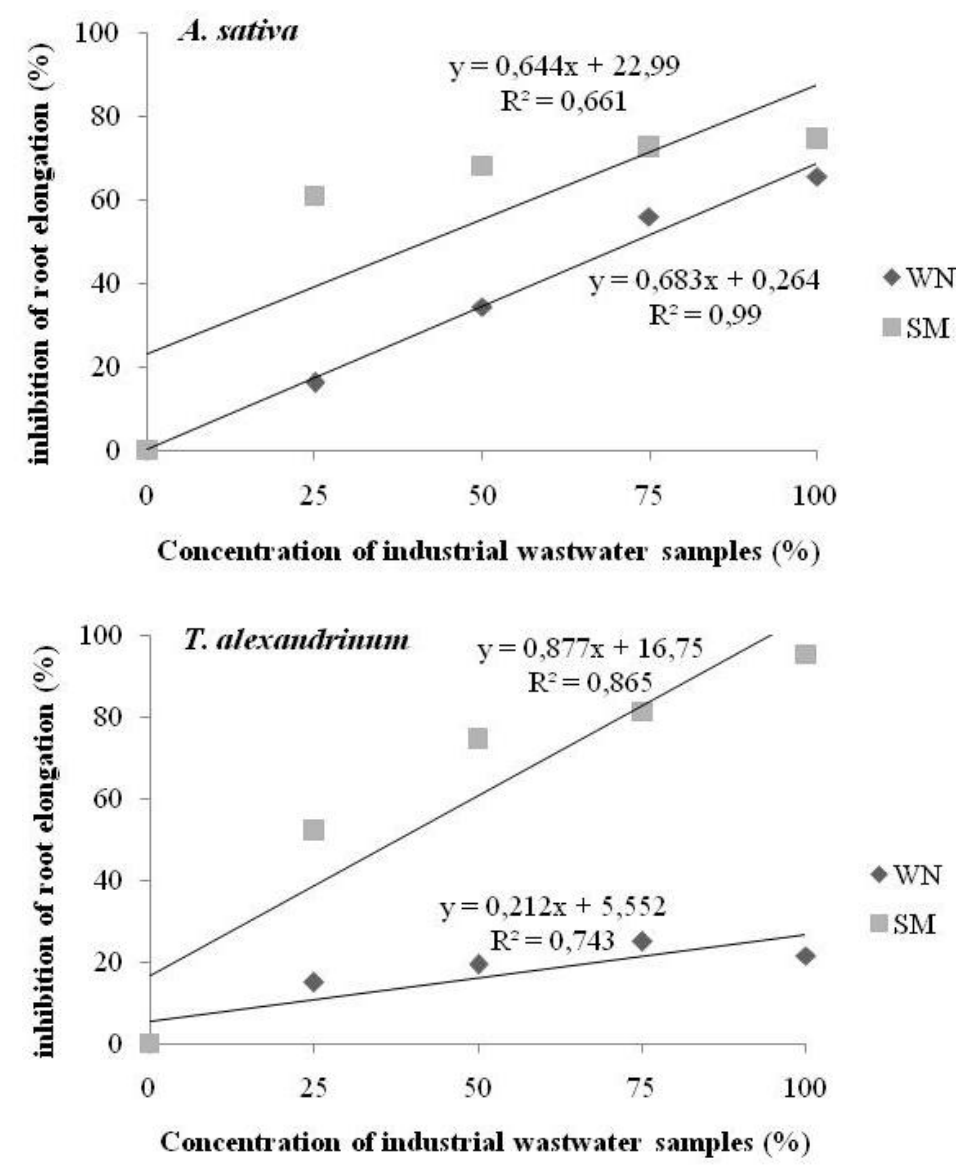

Figure 3. Toxic effects of wastewater samples collected during the winter (WN) and summer season (SM) on the root elongation inhibition of A. sativa and T. alexandrinum 


$$
-333-
$$

Moreover, the SM samples inhibited the root growth of the two plant tested in a dose-dependent manner and these effects were statistically significant $(P<0.05)$ at concentrations of $25 \%$.

Table 3. Regression equations and EC50 for root elongation of A. sativa and T. alexandrinum exposed to samples collected during the winter $(W N)$ and summer season (SM)

\begin{tabular}{lcccc}
\hline Plant species & sample & Regression Equation & $\boldsymbol{R}^{2}$ & EC50 (\%) \\
\hline A. sativa & WN & $\mathrm{y}=0,683 \mathrm{x}+0,264$ & $R^{2}=0,99$ & 72.8 \\
& $\mathrm{SM}$ & $\mathrm{y}=0,644 \mathrm{x}+22,99$ & $R^{2}=0,661$ & 41.9 \\
\hline T. alexandrinum & WN & $\mathrm{y}=0,212 \mathrm{x}+5,552$ & $R^{2}=0,743$ & - \\
& SM & $\mathrm{y}=0,877 \mathrm{x}+16,75$ & $R^{2}=0,865$ & 37,9 \\
\hline
\end{tabular}

- : Not determined

Further, according to the regression equations (Table 3.) based on the inhibition of root elongation by the SM sample treatments, the $T$. alexandrinum was slightly more sensitive than A. sativa (EC50 37.9 and $41.9 \%$ respectively). In fact, the water samples collected during summer (SM) were found to be the most toxic than that of WN, with the lowest EC50 values recorded (Table 3.).

\section{Genotoxicity}

Genotoxicity effects of the industrial effluents rejected into the Reghaïa Lake were evaluated by means of cytogenetic analyses considering mitotic index values (MI), micronucleus assay (MN) and pollution index (PI) on root tips of two different plant species A. sativa L. and T. alexandrinum L. (Table 4.).

Table 4. Genotoxic effects on A. sativa and T. alexandrinum tip cells of samples collected during the winter (WN) and summer season (SM) at different concentrations

\begin{tabular}{|c|c|c|c|c|c|c|c|}
\hline \multicolumn{2}{|c|}{ Sample } & \multicolumn{3}{|c|}{ Avena sativa } & \multicolumn{3}{|c|}{ Trifolium alexandrinum } \\
\hline & & $\mathrm{MI}(\%)$ & MN (\%o) & PI & MI (\%) & $\mathrm{MN}(\%)$ & PI \\
\hline \multirow[t]{4}{*}{ WN } & $25 \%$ & $47.3 \pm 2.4 \mathrm{NS}$ & $2.7 \pm 0.6 \mathrm{NS}$ & 1.1 & $45.6 \pm 6.1 \mathrm{NS}$ & $1.9 \pm 0.2 \mathrm{NS}$ & 1.2 \\
\hline & $50 \%$ & $41.6 \pm 3.2^{* *}$ & $2.9 \pm 1.3 \mathrm{NS}$ & 1.2 & $45.2 \pm 6.3 \mathrm{NS}$ & $3.5 \pm 1.0 * * *$ & 2.2 \\
\hline & $75 \%$ & $39.8 \pm 3.3^{* * *}$ & $3.5 \pm 0.8 *$ & 1.4 & $45.1 \pm 4.9 \mathrm{NS}$ & $4.7 \pm 1.9 * * *$ & 2.9 \\
\hline & $100 \%$ & $38.8 \pm 4.7^{* * *}$ & $3.7 \pm 2.4^{*}$ & 1.4 & $43 \pm 0.58 * *$ & $4.9 \pm 1.6^{* * *}$ & 3.1 \\
\hline \multirow[t]{4}{*}{$\mathrm{SM}$} & $25 \%$ & $27.9 \pm 3.4^{* * *}$ & $5.8 \pm 2.1 * * *$ & 2.3 & $39.6 \pm 3.3 * * *$ & $6.3 \pm 2.8^{* * *}$ & 3.9 \\
\hline & $50 \%$ & $27.7 \pm 5.3 * * *$ & $7.6 \pm 2.7 * * *$ & 3 & $36.0 \pm 2.0 * * *$ & $8.0 \pm 2.6^{* * *}$ & 5 \\
\hline & $75 \%$ & $26.6 \pm 3.0 * * *$ & $8.1 \pm 2.3 * * *$ & 3.2 & $30.3 \pm 4.2 * * *$ & $10.1 \pm 3.7^{* * *}$ & 6.3 \\
\hline & $100 \%$ & $22.4 \pm 6.1 * * *$ & $8.9 \pm 4.6^{* * *}$ & 3.6 & $27.2 \pm 13.6^{* * *}$ & $10.7 \pm 2.6^{* * *}$ & 6.7 \\
\hline \multicolumn{2}{|c|}{ Negative control } & $47.7 \pm 1.2$ & $2.5 \pm 0.8$ & - & $46.1 \pm 3.3$ & $1.6 \pm 0.9$ & - \\
\hline \multicolumn{2}{|c|}{ Positive controle } & $18.4 \pm 4.9 * * *$ & $9.7 \pm 2.2 * * *$ & 3.9 & $22.7 \pm 1.4^{* * *}$ & $11.2 \pm 4.1^{* * *}$ & 7 \\
\hline
\end{tabular}

Significance level calculated through Tukey tests: $* P<0.05$. $* * P<0.01$. $* * * P<0.001$ and NS: not significant 


\section{Mitotic index $(M N)$}

The results presented in Table 4., show that in relation to the mitotic indices, the samples collected during the summer season (SM) presented a more accented decrease (significant at $P<0.001$ ) than that of winter (WN). Therefore, upon exposure of $A$. sativa root cells to MMS (positive control) and SM samples, mitotic indices (MI) of root meristematic cells decreased significantly $(P<0.001)$ in comparison to that of $T$. alexandrinum (Table 4.). However, the MI were comparable (no significant difference) in the negative control apices of two plant species. As listed in Table 4., the MI decreased markedly $(P<0.01)$ in A. sativa root cells when exposed to concentrations greater than $50 \%$ of $\mathrm{WN}$ samples. However, they did not exert any effects on $T$. alexandrinum MI at any dilution tested, but it was significantly reduced by $6.7 \%$ in response to the undiluted WN samples compared to control. Thus, A. sativa root cells appear to be more sensitive to the cytotoxicity of industrial wastewater in this study.

\section{Micronuclei frequency $(M N)$}

In this study, the highest number of micronuclei (11.2\%o) is recorded in the root cells of $T$. alexandrinum exposed to the positive control, MMS, clearly demonstrates the genotoxic effects of the known mutagen on the root meristematics cell. Moreover, the SM samples effect was more remarkable in T. alexandrinum root cells concerning the huge increases (significant at $P<0.001$ ) of micronuclei emergence (6.3-10.7 of micronuclei per 1,000 cells) while the MN frequency was comparatively lower in the $A$. sativa root cells (5.8-8.9 of micronuclei per 1,000 cells). In the other hand, a lower frequency of $\mathrm{MN}$ was observed after exposure of $A$. sativa $\mathrm{L}$. root cells to $\mathrm{WN}$ samples which is probably due to their lower sensitivity to micronuclei occurrence compared to $T$. alexandrinum. In this case, a significant $(P<0.05)$ increase compared to the control was obtained only at the high concentrations $75 \%$ and $100 \%$ of WN samples for which the increase was about 1.4 and 1.5 times higher. Likewise, an increase in the MN emergence after $\mathrm{WN}$ treatment was also observed in $T$. alexandrinum root cells at the concentrations of 50\%, 75\% and 100\%, the MN was 2.2, 2.9 and 3.1-fold higher than that observed in the negative control.

\section{Chromosome aberrations}

Cytological analysis showed various types of chromosomal abnormalities in different stages of the mitosis cycle. Figures 4. and 5. indicate the chromosomal alteration evidencing the presence of genotoxic substances in samples.

The genotoxic effect caused by SM samples was more pronounced than that of WN, by causing an induction of chromosome aberrations. Micronuclei were one of main aberration types observed in the current study (Fig. 4: B1; B2; C2 and Fig. 5: B1; B2; $\mathrm{B} 3$; $\mathrm{C} 1)$. The morphological alterations in the interphase nuclei (deformed nucleus) (Fig. 4: B1; C1 and Fig. 5: B1; C1), sticky metaphase (Fig. 4: B4; B5) and disturbed metaphase (Fig. 5: C4; B4) were also observed. The occurrence of anaphase with bridges (Fig. 4: C4) and cell death (Fig. 4: C5) were more detected in A. sativa root cells exposed to SM samples, while the nuclear buds (Fig. 5: C2), and small condensed nuclei (Fig. 5: C3) were more often observed in T. alexandrinum L. root cells. 

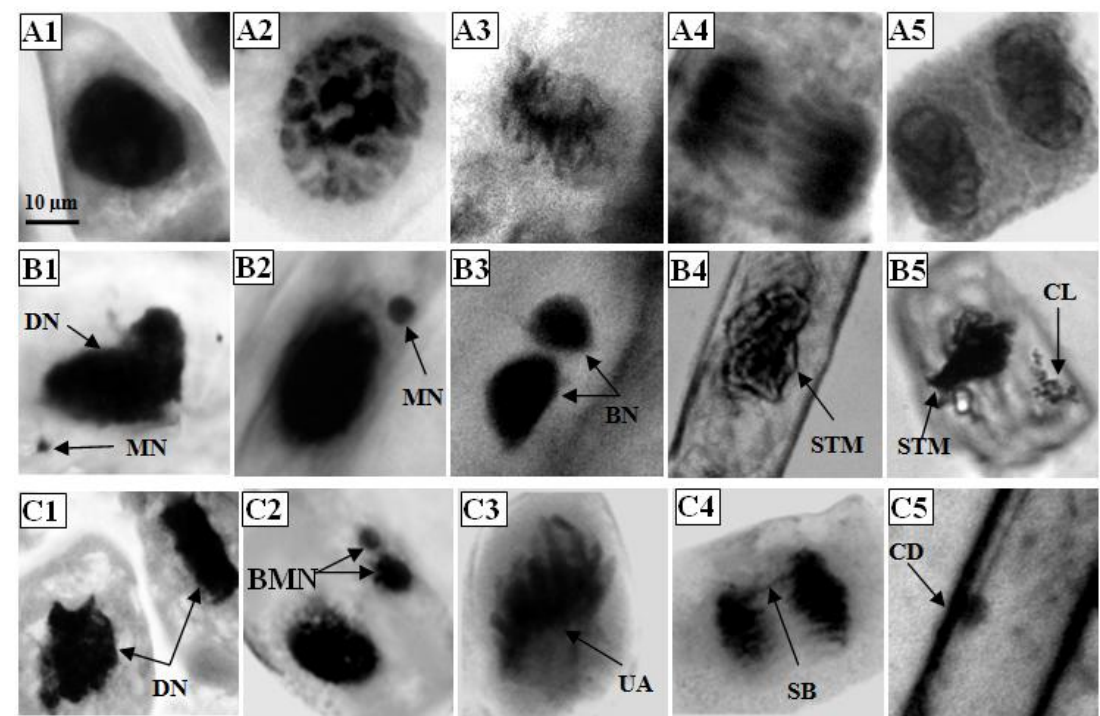

Figure 4. Normal and abnormal chromosome morphology at mitosis of Avena sativa root tip cells.

A: Normal chromosome morphology. 1: interphase; 2: prophase; 3: metaphase; 4: anaphase; 5: telophase. B: Abnormal chromosome morphology in root tip cells treated with undiluted water samples of the winter (WN) season. B1: deformed nucleus (DN) with micronucleus (MN); B2: single micronucleus (MN); B3: binuclei (BN); B4: sticky metaphase (STM); B5: sticky metaphase with chromosome loss (CL).

$\mathrm{C}$ : Abnormal chromosome morphology in root tip cells treated with undiluted water samples of the summer (SM) season. C1: deformed nucleus in interphase; C2: bi-micronuclei (BMN); C3: unipolar anaphase (UA); C4: anaphase with single bridge (SB); C5: cell death (CD).

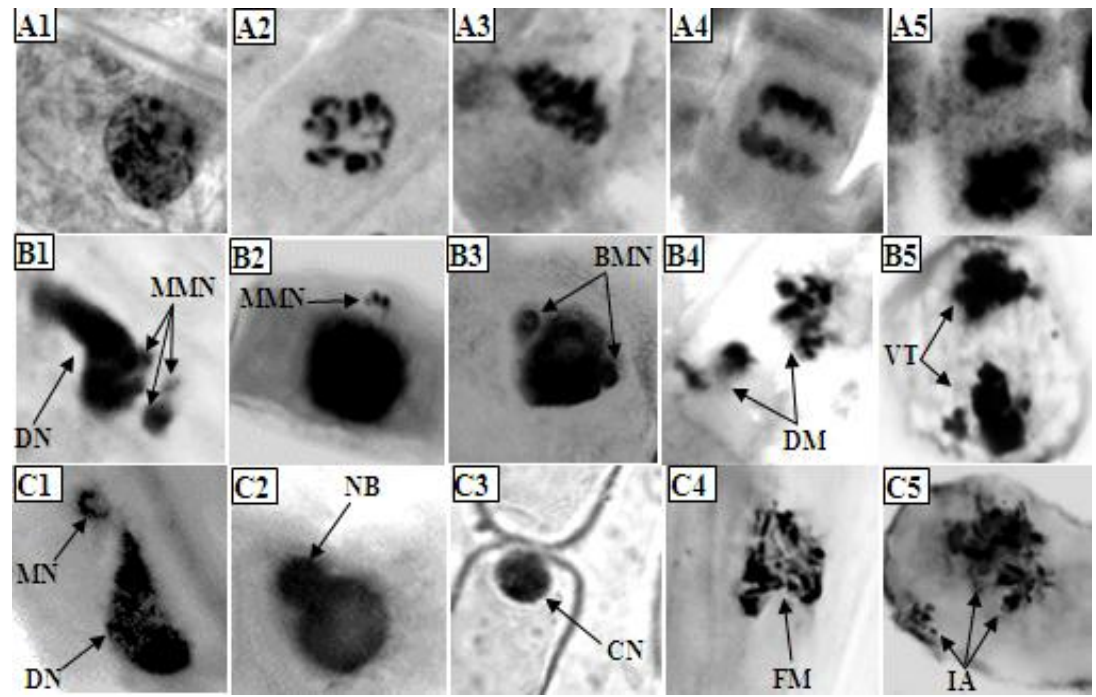

Figure 5. Normal and abnormal chromosome morphology at mitosis of Trifolium alexandrinum root tip cells.

A: Normal chromosome morphology. 1: interphase; 2: prophase; 3: metaphase; 4: anaphase; 5: telophase. B: Abnormal chromosome morphology in root tip cells treated with undiluted water samples of the winter (WN) season. (B1): deformed nucleus with multi- micronuclei (MMN); (B2): multi- micronuclei; (B3): bi-micronuclei; (B4): disturbed metaphase (DM); (B5): vagrant telophase (VT).

$\mathrm{C}$ : Abnormal chromosome morphology in root tip cells treated with undiluted water samples of the summer (SM) season. (C1): deformed nucleus with micronucleus; (C2): nuclear bud (NB); (C3): condensed nuclei $(\mathrm{CN})$; (C4): fragmented metaphase (FM); (C5): overcontraction in chromosomes and polar slip irregularities at anaphase (IA). 


\section{Pollution Index (PI) values}

Generally, levels of pollution are divided into four grades based on PI values: 0-1.5, no pollution; $1.5-2$, light pollution; $2-3.5$, medium pollution; and, above 3.5 , heavy pollution (Jin and Chen, 1998). It has been found that WN samples had the lower PI values in these studies; because at all concentrations tested on A. sativa apices, PI values were all bellow 1.5, which indicates that the $\mathrm{WN}$ samples tested were not polluted. On the contrary, the PI values increased in T. alexandrinum with the increase of $\mathrm{WN}$ water concentrations (from $\mathrm{PI}=1.2$ : no pollution to $\mathrm{PI}=3.06$ : medium pollution), which appears logical as the concentration of pollutants becomes higher.

This result suggests that $T$. alexandrinum apices are by far high sensitive to the occurrence of MN than that of A. sativa. In concordance with the highest number of micronuclei recorded in both Avena and Trifolium apices, SM samples (at all concentrations), with the highest PI values (all above 3.5 ) reaches heavy pollution level.

\section{Discussion}

El Biar River (Reghaïa, Algiers) which was chosen for screening for the presence of genotoxic substances, receives untreated industrial effluents from Reghaïa-Rouiba industrial plants which will be subsequently discharge into the Reghaïa Lack. In this study, the wastewaters were collected at the mouth of El Biar River during two periods of the year 2015: the winter season (WN) and summer (SM). Besides the chemical analysis, phytotoxicity, cytotoxicity and genotoxicity assays were carried out to assess efficiently the toxic effects of industrial wastewater on Avena sativa and Trifolium alexandrinum plant system.

\section{Physico-chemical analyses}

Physico-chemical analyses of wastewater samples showed that the WN samples are less contaminated than the SM ones, which can be explained by the different characteristics related to the Mediterranean climate seasonality. This contrasted climate is characterized by hot and dry summer, while the winter season is rather cold and rainy. Meteorological data for the periods of sampling showed a great variation, mainly related to the monthly temperature mean and rainfall volume (Table 5.). SM samples were taken in a period with almost no precipitation $(0 \mathrm{~mm})$; they are the most contaminated, likely due to low precipitation in this dry season which suggests a higher concentration of pollutants in the water of river. The increase in temperature, as observed in summer, promotes water evaporation and can elevate the dissolution of substances in water, including some metals (Delpla et al., 2009; Mazzeo and Marin-Morales, 2015).

Table 5. Meteorological data for the water samples collection periods of the Reghaïa region.

\begin{tabular}{ccccccc}
\hline Collection period & $\begin{array}{c}\text { Maximum } \\
\text { temperature } \\
\left({ }^{\circ} \mathrm{C}\right)\end{array}$ & $\begin{array}{c}\text { Minimum } \\
\text { temperature } \\
\left({ }^{\circ} \mathrm{C}\right)\end{array}$ & $\begin{array}{c}\text { Mean } \\
\text { temperature } \\
\left({ }^{\circ} \mathrm{C}\right)\end{array}$ & $\begin{array}{c}\text { Relative } \\
\text { humidity of the } \\
\text { air }(\%)\end{array}$ & $\begin{array}{c}\text { Rainfall } \\
(\mathrm{mm})\end{array}$ \\
\hline Winter & January & 16.9 & 5.1 & 10.4 & 78.4 & 72.14 \\
2015 & February & 15.4 & 6 & 10.5 & 77.6 & 90.93 \\
\hline Summer & July & 34.7 & 20.1 & 27.5 & 62.8 & 0 \\
2015 & August & 33.4 & 22.1 & 27.5 & 66.4 & 0 \\
\hline
\end{tabular}

The values were obtained by calculating the mean of the daily values. 


$$
-337 \text { - }
$$

However, much precipitation occurred in the winter seasons $(72.14 \mathrm{~mm}$ in January and $90.93 \mathrm{~mm}$ in February 2015.) and thus, WN samples were less contaminated. This supports the assumption that dilution has led to lower concentrations of potential contaminants in the water phase. Industrial effluents characteristically contain a complex mixture of organic and inorganic pollutants. The previous studies reported that high concentrations of potentially toxic metals were detected at the upstream of the lake (Thibault et al., 2006; Taleb et al., 2008).

\section{Germination test}

The convenient methods to study the toxicity of pollutants to higher plants are the experiment concerning seed germination and root elongation, consequently, the seed germination rate of plants was frequently used as a phytotoxicity assay for testing the metal effects (Chen et al., 2012). Among the most sensitive plant species recommended by the OECD (1984), US EPA (1982) and US FDA (1987) are dicotyledons such as clover (Trifolium). In this study, the germination of $T$. alexandrinum was more sensitive to the metal containing wastewater than that of A. sativa which seems not to be influenced by WN samples exposure and may not be a sensitive test for evaluating toxicity. According to Gong and Wilke, 2001 and Wang and Zhou, 2005a, the germination is insensitive when the concentration of a pollutant is low, because a plant embryo can absorb nutrition from the embryo to accomplish its germinating process. However, the toxic influence of SM on T. alexandrinum was manifested itself as depressed germination which meant that germination is sensitive when the the complex of pollutants is high (Wang and Zhou, 2005b).

\section{Root elongation test}

The inhibition of root elongation is considered to be the first evident effect of metal toxicity in plants. Since roots are the first organ to come in contact with the metals, their growth is affected largely. In general, there was a reduction in root elongation in all assays involving industrial wastewater. The SM samples had the highest impact on inhibition of root elongation; this can be related to the complex of contaminants present in these samples, particularly heavy metals that are reported in the literature to be toxic to plant growth at the concentrations actually found in the present water samples. Thus, inhibition of growth can result from the absence of necessary nutrients in the water or the presence of insoluble compounds, which prevent the uptake of nutrients (Gong and Wilke, 2001). The results suggest that $T$. alexandrinum root elongation was well suited for testing toxicity of wastewater. It should be noted that $A$. sativa has often shown low sensitivity to metal contamination (Wilke et al., 1998; Loureiro et al., 2006). The ecotoxicological effects under the combined pollution were not only related to chemical properties of pollutants but also dependent on the combination of concentrations of pollutants in ecosystems (Zhou et al., 2004). In this context, the results from the present study indicated that, perhaps the combination of organic pollutants and heavy metals at the low concentration will reduce the activity of heavy metals and possibly will inhibit them to enter the root system. In that way, the toxic effects of WN sample decreased. 


\section{Genotoxicity}

\section{Mitotic index}

The present study reveals that industrial effluents dumped in the Reghaïa Lake present a high cytotoxicity on the root meristematic cells of both plant species, in respect to the negative control. Our results showed that the SM samples were the most cytotoxic. This influence was more accented in the A. sativa apices in comparison to that in T. alexandrinum. The depression of miotic index in A. sativa root cells may likely be due to the retardation of cell division in the root apices or even the inhibition of mitotic activity which may induce cell death, phenomenon well observed in A. sativa exposed to undiluted SM samples. Inhibition of mitotic activity above $78 \%$ caused lethal effect, while the inhibition above 50\% usually has sublethal effect (Sharma, 1983; Wang et al., 2007). This indicates, qualitatively, the presence of compounds with some degree of cytotoxicity, containing in effluents from industries situated in the upstream of El Biar River. The decline of mitotic index has been attributed to the effect of environmental chemicals including heavy metals on DNA/protein synthesis of the biological system (Barbosa et al., 2010; Hemachandra and Pathiratne, 2015). The cytotoxic effect may not be contributed by a single compound, but is more likely to reflect the cumulative effects of contaminants present in water. Heavy metals, individually or in combination, may exert a strong inhibitory effect on the cell division (Unyayar et al., 2006).

\section{Micronuclei test}

As far as micronuclei emergence is concerned, A. sativa L. appears to be the more resistant to genotoxic effects of SM and WN effluent among the two experimental plants, since it shows the minimum of micronuclei formation in comparison to $T$. alexandrinum. Differences in the plant response to toxic substances reflect the different genetic and physiological assets of each one of them (Cotelle et al., 1999). In A. sativa, for example, MN frequency seems no/less affected by the WN exposure. The $T$. alexandrinum apices showed more sensibility in the MN occurrence. Furthermore, the SM wastewaters induced considerably stronger genetic damage towards $T$. alexandrinum cells than the WN ones which produced less of micronuclei frequency. The results imply a seasonal difference in genotoxicity induced by wastewater samples. In the other hand, micronuclei test (MN) is an efficient test system to analyze the mutagenic effects promoted by environmental pollutants (Ma et al., 1995). The micronucleus is composed either of small chromatin fragments which arise as a result of chromosomal breakage or of whole chromosomes that do not migrate during anaphase as a result of spindle dysfunction (Ma et al., 1995; Leme and Marin-Morales, 2009). Chromosomal aberrations derived from the aneugenic and clastogenic action of the polluants, also observed in both plant root cells, can give rise to micronuclei. So that the $\mathrm{MN}$ presented in these root cells showed different sizes.

\section{Chromosomal aberrations}

Chromosomal aberrations are the consequence of DNA double-strand break which was unrepaired or repaired improperly (Maluszynska and Juchimiuk, 2005). The types of chromosomal abnormalities induced in A. sativa root tip cells exposed to wastewaters reflect more aneugenic effects due to spindle dysfunctions than clastogenic effects due 
to chromosomal breaks. In the present results, the stickiness and anaphase bridges were observed with the test samples. The sticky chromosomes due to chromatin dysfunction (Leme and Marin-Morales, 2009) reflect highly toxic effects, usually of an irreversible type and probably lead to cell death (Liu et al., 1992). Sticky chromosomes have been reported in Allium roots after treatment with various heavy metals such as $\mathrm{Hg}, \mathrm{Ni}$, and $\mathrm{Cu}$ (Monte Egito et al., 2007). While the chromosome bridges in the anaphase and telophase indicate chromosomal breaks due to the clastogenic effects (Radic et al., 2010; Masood and Malik, 2013). The other effects observed in T. alexandrinum are vagrant chromosomes, disturbed metaphase (spindle failure) and nuclear buds. According to El-Ghamery et al., (2003), the induction of vagrant chromosomes may lead to the separation of unequal number of chromosomes in the daughter nuclei and subsequently increase the risk for aneuploidy (Leme and Marin-Morales, 2009). In the other hand, nuclear buds arise as a result of the elimination of exceeding genetic material derived from the polyploidization process (Fernandes et al., 2007).

Our results are in accordance with recent ecotoxicological studies that suggest the utility of plant mutagenicity/genotoxicity assays in water quality monitoring programs (Radić et al., 2010; Yu et al., 2011; Firbas and Amon, 2014; Srivastava et al., 2014; Pathiratne et al., 2015). This study demonstrates the efficacy of the new plant test system for screening the genotoxic potential of industrial wastewaters and may agrue the possibility use of plants that are not considered as a model plant system for genotoxicity test, provided that the choice of plants is based on a specific goal; in our case, the choice was made on the basis of their economical and agricultural values in studied area. The present study may lead to regulations which should be taken as control measures for these discharges. Therefore, it is suggested that the release of effluent from Reghaïa-Rouiba industrial area should be done after appropriate treatment and rejection into water resources should be minimized.

\section{REFERENCES}

[1] Alomary, A. A., Belhadj, S. (2007): Determination of heavy metals (Cd, Cr, Cu, Fe, Ni, $\mathrm{Pb}, \mathrm{Zn}$ ) by ICP-OES and their speciation in Algerian Mediterranean Sea sediments after a five-stage sequential extraction procedure. - Environmental Monitoring and Assessment 135: 265-280.

[2] Barbosa, J. S., Cabral, T. M., Ferreira, D. N., Agnez-Lima, L. F., Batistuzzo de Medeiros, S. R. (2010): Genotoxicity assessment in aquatic environment impacted by the presence of heavy metals. - Ecotoxicology and Environmental Safety 73: 320-325.

[3] Chen, F., Gao, J., Zhou, Q. (2012): Toxicity assessment of simulated urban runoff containing polycyclic musks and cadmium in Carassius auratus using oxidative stress biomarkers. - Environmental Pollution 16: 291-297.

[4] Cotelle, S., Masfaraud, J. F., Ferard, J. F. (1999): Assessment of the genotoxicity of contaminated soil with the Allium/Vicia-micronucleus and the Tradescantia-micronucleus assays. - Mutation Research 426(2): 167-171.

[5] Delpla, I., Jung, A.V., Baures, E., Clement, M., Thomas, O. (2009): Impacts of climate change on surface water quality in relation to drinking water production. - Environment International 35: 1225-1233.

[6] El-Ghamery, A. A., El-Kholy, M. A., El-Yousser, A. (2003): Evaluation of cytological effects of $\mathrm{Zn}^{2+}$ in relation to germination and root growth of Nigella sativa $\mathrm{L}$. and Triticum aestivum L. - Mutation Research 537: 29-41. 
[7] Fatima, R. A., Ahmad, M. (2006): Genotoxicity of industrial wastewaters obtained from two different pollution sources in northern India: A comparison of three bioassays. Mutation Research 609: 81-91.

[8] Fernandes, T. C. C., Mazzeo, D. E. C., Marin-Morales, M. A. (2007): Mechanism of micronuclei formation in polyploidizated cells of Allium cepa exposed to trifluralin herbicide. - Pesticide Biochemistry and Physiology 88: 252-259.

[9] Filkowski, J., Besplug, J., Burke, P., Kovalchuk, I., Kovalchuk, O. (2003): Genotoxicity of 2,4-D and dicamba revealed by transgenic Arabidopsis thaliana plants harboring recombination and point mutation markers. - Mutation Research 542(1) 23-32.

[10] Firbas, P., Amon, T. (2014): Chromosome damage studies in the onion plant Allium cepa L. - Caryologia 67 (1): 25-35.

[11] Garg, V.K., Kaushik, P. (2007): Influence of textile mill wastewater irrigation on the growth of sorghum cultivars. - Applied Ecology And Environmental Research 6(2): 1-12.

[12] Gong, P., Wilke, B. M. (2001): Evaluation and refinement of a continuous seed germination and early seedling growth test for the use in the eco-toxicological assessment of soils. - Chemosphere 44: 491-500.

[13] Grant, W. F. (1978): Chromosome aberrations in plants as a monitoring system. Environmental Health Perspectives 27: 37-43.

[14] Hemachandra, C. K., Pathiratne, A. (2015): Assessing toxicity of copper, cadmium and chromium levels relevant to discharge limits of industrial effluents into inland surface waters using common onion, Allium cepa bioassay. - Bulletin of Environmental Contamination and Toxicology 94: 199-203.

[15] International organization for standardization (ISO). (2007) : Qualité de l'eau - dosage d'éléments choisis par spectroscopie d'émission optique avec plasma induit par haute fréquence (ICP-OES). norme 11885. ISO. geneva.

[16] Kamal, K. P., Maheswar, L., Brahma, B. P. (1992): Monitoring and assessment of mercury pollution in the vicinity of a chloralkali plant. II Plant-availability, tissueconcentration and genotoxicity of mercury from agricultural soil contaminated with solid waste assessed in barley (Hordeum vulgare L.). - Environmental Pollution 76 (1): 33-42.

[17] Kumar, S. (2010): Effect of 2, 4-D and isoproturon on chromosomal disturbances during mitotic division in root tip cells of Triticum aestivum L. - Cytology and Genetics 44(2): 79-87.

[18] Leme, D. M., Marin-Morales, M. A. (2009): Allium cepa test in environmental monitoring: a review on its application. - Mutation Research 682: 71-81.

[19] Levan, A. (1938): The effect of olchicines on root mitoses in Allium. - Hereditas 24: 471476.

[20] Li, F., Liu, P., Wang, T., Bian, P., Wu, Y., Wu, L., Yu, Z. (2010): Genotoxicity/mutagenicity of formaldehyde revealed by the Arabidopsis thaliana plants transgenic for homologous recombination substrates. - Mutation Research 699: (1) 3543.

[21] Liu, X., Tang, L., Yang, L., Zhang, X., Wang, L., Yu, F. (2015): Genotoxicity evaluation of irrigative wastewater from Shijiazhuang City in China. - Plos One 10(12): e0144729. doi:10.1371/journal.pone.0144729.

[22] Llorente, M. T., Parra, J. M., Sanchez-Fortun, S., Castano, A. (2012): Cytotoxicity and genotoxicity of sewage treatment plant effluents in rainbow trout cells (RTG-2). - Water Research 46: 6351-6358.

[23] Loureiro, S., Santos, C., Pinto, G., Costa, A., Monteiro, M., Nogueira, A. J. A., Soares, A. M. V. M. (2006): Toxicity assessment of two soils from Jales Mine (Portugal) using plants: Growth and biochemical parameters. - Archives of Environmental Contamination and Toxicology 50: 182-190.

[24] Ma, T. H., Xu, Z., Xu, C., McConnell, H., Rabago, V. E., Arreola, G. A., Zhang, H. (1995): The improved Allium/Vicia root tip micronucleus assay for clastogenicity of environmental pollutants. - Mutation Research 334: 185-195. 


$$
-341 \text { - }
$$

[25] Maluszynska, J., Juchimiuk, J. (2005): Plant genotoxicity: a molecular cytogenetic approach in plant bioassays, plant genotoxicity. - Archives of Industrial Hygiene and Toxicology 56(2): 177-184.

[26] Manier, N., Deram, A., Le Curieux, F., Marzin, D. (2009): Comparison between new wild plant Trifolium repens and Vicia faba on their sensitivity in detecting the genotoxic potential of heavy metal solutions and heavy metal-contaminated. - Soils Water Air Soil Pollution 202: 343-352.

[27] Masood, F., Malik, A. (2013): Cytotoxic and genotoxic potential of tannery waste contaminated soils. - Science of the Total Environment 444: 153-160.

[28] Mazzeo, D. E. C., Marin-Morales, M. A. (2015): Genotoxicity evaluation of environmental pollutants using analysis of nucleolar alterations. - Environmental Science and Pollution Research 22: 9796-9806.

[29] Mielli, A., Matta, M.E.M., Nersesyan, A., Saldiva, P.H.N., Umbuzeiro, G.A., (2009): Evaluation of the genotoxicity of treated urban sludge in the Tradescantia micronucleus assay. - Mutation Research 672: 51-54.

[30] Monarca, S., Feretti, D., Zani, C., Rizzoni, M., Casarella, S., Gustavino, B. (2005): Genotoxicity of drinking water disinfectants in plant bioassays. Environmental and Molecular Mutagenesis 46: 96-103.

[31] Monte Egito, L. M., Das Gracas Medeiros, M. M., Batistuzzo de Medeiros, S. R., AgnezLima, L. F. (2007): Cytotoxic and genotoxic potential of surface water from the Pitimbu river, northeastern/RN Brazil. - Genetics and Molecular Biology 30: 435-441.

[32] Organization for Economic Cooperation and Development (OECD). (1984): Terrestrial plants, Growth test. Guidelines for testing of chemicals, no. 208. OECD, Paris.

[33] Pathiratne, A., Hemachandra, C. K., De Silva, N. (2015): Efficacy of Allium cepa test system for screening cytotoxicity and genotoxicity of industrial effluents originated from different industrial activities. - Environmental Monitoring and Assessment 187: 730-742.

[34] Radić, S., Stipanicev, D., Vujcic, V., Rajcic, M. M., Sirac, S., Pevalek-Kozlina, B. (2010): The evaluation of surface and wastewater genotoxicity using the Allium cepa test. - Science of the Total Environment 408: 1228-1233.

[35] Sang, N., Li, G., Xin, X. (2006): Municipal landfill leachate induces cytogenetic damage in root tips of Hordeum vulgare. - Ecotoxicology and Environmental Safety 63 (3): 469473.

[36] Sharma, C.B.S.R. (1983): Plant meristems as monitors of genetic toxicity of environmental chemicals. - Current Science Association 52: 1000-1002.

[37] Siddiqui, A. H., Tabrez, S., Ahmad, M. (2011): Validation of plant based bioassays for the toxicity testing of Indian waters. - Environmental Monitoring and Assessment 179: 241-253.

[38] Singh, M., Das, A., Singh, D., Maiti, P., Shabbir, M., Das, A. (2014): High genotoxicity of shipyard contaminants on Allium cepa and calf thymus DNA. - Environmental Chemistry Letters 12: 321-327.

[39] Srivastava, A. K., Kumar, R. R., Singh, A. K. (2014): Cell cycle stage specific application of municipal landfill leachates to assess the genotoxicity in root meristem cells of barley (Hordeum vulgare). - Environmental Science and Pollution Research 21: 13979-13986.

[40] Taleb, A., Chaabane, T., Taha, S., Maachi, R. (2008): Treatment of heavy metals by nanofiltration present in the Lake Reghaïa. - Desalination 22: 277-283.

[41] Thibault, M., Bouazouni, O., Hadj Kaddour, B., Moali, A. (2006): Plan de gestion de la réserve naturelle du Lac de Réghaia, Alger. Direction Générale des Forets, Ministère de l'Agriculture et du Développement Rural. Algérie. Projet life3, TCY/INT/031.

[42] Unyayar, S., Celik, A., Cekic, F. O., Gozel, A. (2006): Cadmium-induced genotoxicity, cytotoxicity and lipid peroxidation in Allium sativum and Vicia faba. - Mutagenesis 21:77-81. 
[43] US Environmental Protection Agency. (1982): Seed germination/root elongation toxicity tests EC12. Office of Toxic Substances, Washington, DC.

[44] US Food and Drug Administration. (1987): Seed germination and root elongation, environmental assessment technical assistance document 406. Centre for Food Safety and Applied Nutrition, Center for Veterinary Medicine, Washington, DC.

[45] Wang, M. E., Zhou, Q. X. (2005): Single and joint toxicity of chlorimuronethyl, cadmium and copper acting on wheat Triticum aestivum. - Ecotoxicology and Environmental Safety 60: 169-175.

[46] Wang, X. F., Zhou, Q. X. (2005): Ecotoxicological effects of cadmium on three ornamental plants. - Chemosphere 60: 16-21.

[47] Wang, L. S., Hu, H. Y., Ta, C. H., Tian, J., Wang, C. (2007): Changes of Genotoxicity and influences of ammonia nitrogen during the process of disinfection with chlorine dioxide and chlorine. - Environmental science 28(3): 603-606.

[48] Wilke, B. M., Winkel, B., Fleischmann, S., Gong, P. (1998): Higher plant growth and microbial toxicity tests for the evaluation of the ecotoxic potential of soils. - In: Telford, T. (ed.) Contaminated Soils '98, London.

[49] Yu, J., Ho, W. T., Lu, H. M., Yang, Y. F. (2011): Study on water quality and genotoxicity of surface microlayer and subsurface water in Guangzhou section of Pearl River. Environmental Monitoring and Assessment 174: 681-692.

[50] Zhou, Q. X., Cheng, Y., Zhang, Q. (2004): Quantitative analyses of relationships between ecotoxicological effects and combined pollution. - Science in China 47: 332-339. 